\title{
HANS KELSEN AND THE TRANSCENDENTAL METHOD
}

\section{Dr Carsten Heidemann, Kiel Bar Association*}

The concept of a "transcendental method" is met quite often in the writings of neo-Kantian philosophers, and it can be found in several publications of legal theorist Hans Kelsen from his neo-Kantian period as well. In what follows, this concept and the way Kelsen makes use of it in his legal theory will be examined.

\section{FIRST PART: KANT, COHEN, AND KELSEN}

\section{Kant, Cohen, and the transcendental method}

The term "neo-Kantianism" denotes a large number of different philosophical theories that around 1900, were setting the tone in German academic philosophy. The common denominator of neo-Kantian theories is that they were produced in the period between 1870 and 1930 (approximately), and that they aim at reviving and developing Kant's transcendental philosophy. But in constructing theories on this rather vague basis, neo-Kantian philosophers diverge. It is common to distinguish two main trends of neo-Kantianism: the Heidelberg School, led by Wilhelm Windelband and Heinrich Rickert, and the Marburg School, led by Hermann Cohen. The Heidelberg School is famous for its central concept of "value" and for employing it in establishing the autonomy of the cultural sciences; the Marburg School is famous for its "logicist-but-dynamicist" theory of knowledge and for reconstructing transcendental philosophy as a (meta) theory of science.

The transcendental method is at the core of a number of neo-Kantian theories, being the method of discovering non-empirical necessary conditions for any knowledge. As far as I can see, the term "transzendentale Methode" was not used by Kant himself. Something to which this term might be applied can be found in Kant's writings, though. Kant takes the main task of his theoretical philosophy to be reconstructing the universal conditions of the possibility of objective empirical knowledge, and he tries to achieve this aim principally by a method he calls "transcendental deduction": To prove the objective validity of the categories, taken as fundamental concepts of understanding, and thus of the scientific judgements employing these categories, Kant's transcendental deduction starts from an indubitable premise: the transcendental unity of self-awareness (transzendentale Einheit der Apperzeption), which is necessarily presupposed in any act that might be called "cognition of objects". Kant then goes on to investigate into what is necessarily "implied" by this indubitable premise. As is well known, the

\footnotetext{
* An earlier version of this paper was presented at the one-day colloquium Law and Objectivity in the Work of Hans Kelsen that was organised on 23 Nov 2003 by the Forum of Law and Philosophy at the Queen's Law School. Warm thanks are due to Bonnie Litschewski Paulson for help in matters of English style and grammar.
} 
conclusion is that in any piece of empirical knowledge the categories, which can be identified by the corresponding functions of judgements, are necessarily employed. The central importance of the transcendental deduction is that Kant, in spite of his concept of a "thing-in-itself", is an idealist: For him, knowledge does not just "reflect" a given objective world, rather, the objective world is constituted by cognition itself. Accordingly, epistemology and ontology merge, and the categories are not only the basic concepts of understanding, they are the basic elements of objective reality, as well. ${ }^{1}$

Cum grano salis, this method of transcendental deduction might be called Kant's "transcendental method". However, Hermann Cohen, who introduced the term into neo-Kantian philosophy, explains it in different terms. He maintains that

"if knowledge [Erkenntnis] is taken not as a form of consciousness, but as a factum which has constituted itself in science and continues to constitute itself on a given basis, then the object of our examination is not any subjective reality but a fact that, though still changing and increasing, is objectively given and grounded in principles, it is not our cognitive apparatus or the process of cognition, but science as its result. At this point an apparent question arises: Which are the presuppositions responsible for the certainty of the scientific fact?"2

And to answer this question is, according to Cohen, the task of the transcendental method. It is not difficult to see the difference between Cohen's and Kant's conceptions. While Kant's indubitable starting-point is the transcendental unity of self-awareness - the necessity that the thought "I think" might accompany all our ideas - Cohen starts by presupposing what actually has to be proven: the objectivity of the results of the institutionalised sciences.

In fact, Kant himself anticipated the difference between these two methods. In the Prolegomena to any Future Metaphysics, which are meant to be an easily understandable introduction and summary to the Critique of Pure Reason, he distinguishes an analytic or regressive method of theorising from a synthetic or progressive method and claims to have employed the latter in the Critique and the former in the Prolegomena:

"[Employing the synthetic method means] inquiring within pure reason itself, and seeking to determine within this source both the elements and the laws of its pure use, according to principles. This work is difficult and requires a resolute reader to think himself little by little into a system that takes no foundation as given except reason itself, and that therefore

${ }^{1}$ For the transcendental deduction see I. Kant, Kritik der reinen Vernunft (ed. by W. Weischedel, Frankfurt/M. 1974), §§ 13-27. There are significant differences in the presentation of the deduction in the first and second editions of the Critique, which I will neglect in this context.

2 H. Cohen, Das Prinzip der Infinitesimal-Methode und seine Geschichte (ed. by W. Flach, Frankfurt/M. 1968), 47-8 (translation C.H.). 
tries to develop cognition out of its original seeds without relying on any fact whatever. [Prolegomena, on the other hand, must] rely on something already known to be dependable, from which we can go forward with confidence and ascend to the sources, which are not yet known. [. . .] The methodological procedure of prolegomena, and especially of those that are to prepare for a future metaphysics, will therefore be analytic. Fortunately, [. . .] we can confidently say that some pure synthetic cognition a priori is actual and given, namely, pure mathematics and pure natural science."

Though in secondary literature concerning Kant's writings it is not settled how far this distinction between the analytic/regressive and the synthetic/progressive method reaches, it seems obvious that what Cohen has in mind is something akin to Kant's regressive method. And the reason why he does not want to adopt the progressive method is evident as well: On the one hand, Cohen, like most neo-Kantians, was an opponent of "psychologism", i.e. of the project to reduce epistemology or cognitive philosophy to psychology. But to search into "reason itself" as a startingpoint to discover self-awareness as necessarily accompanying all our ideas smacks of introspective psychology - even though Kant points out that the transcendental unity of self-awareness must be distinguished from any empirical form of consciousness. On the other hand, the rapid development of mathematics and natural sciences at the end of the nineteenth century made it doubtful that there really were any universal principles valid independent of what was taken for granted according to the best standards of institutionalised science at a given time. Hence, Cohen combines the regressive method with a rather peculiar dynamic theory of universal principles of cognition. ${ }^{4}$

The transcendental method almost came to be part of the common lore of neo-Kantianism; for other prominent neo-Kantian philosophers, like Heinrich Rickert, borrowed the conception, if not the terminology, from Cohen and used it in a similar way. ${ }^{5}$

To summarise: The conception of the "transcendental method" as the characteristic method of transcendental philosophy leading to a priori valid non-empirical conditions for knowledge is an invention of the neo-Kantian Hermann Cohen. Unlike Kant's transcendental deduction of the categories, the transcendental method does not take the unity of self-awareness, located in pure reason itself, as its starting-point, but it is based on the results of the established sciences. It follows that transcendental philosophy no longer has the character of a "critique of pure reason" but rather the character of an

3 I. Kant, Prolegomena zu einer jeden künftigen Metaphysik, die als Wissenschaft wird auftreten können (ed. by W. Weischedel, Frankfurt/M. 1988), 274-5 (A 38-9; translation from Prolegomena to any future metaphysics that will be able to come forward as science (translated by G. C. Hartfield; Cambridge 1997), 25-6).

4 See esp. his Logik der reinen Erkenntniss. System der Philosophie, Erster Teil (Berlin 1902).

5 Cf. H. Rickert, "Zwei Wege der Erkenntnistheorie", in: Kant-Studien 14 (1909), 169-228, at 174, 193, 226. 
analysis of the necessary presuppositions of the "results of the best sciences in existence".

\section{Kelsen's conception of the transcendental method}

In his first major publication from 1911 called Main Problems of Public Law Theory, which already contains many of the major tenets of his later Pure Theory of Law, Kelsen does not consciously make use of neo-Kantian theories. In fact, the theory of law developed in this book as yet lacks a systematic epistemological basis. In the preface to the second edition of the Main Problems (published in 1923), Kelsen avows that his attention was first drawn towards the theory of Hermann Cohen by a review of his book in 1912, which pointed out certain similarities between the works of both authors. ${ }^{6}$ It induced Kelsen to borrow from neo-Kantian conceptions to construct an epistemological basis for his legal theory. Still, throughout his neo-Kantian phase, lasting approximately from 1916 to $1934,{ }^{7}$ Kelsen had a rather ambivalent position towards Cohen's philosophy. On the one hand, Cohen's explanation of the transcendental method offered an ingenious way for Kelsen to solve several fundamental problems of his legal theory. Furthermore, Cohen - in his Ethics of Pure Will - had paved the way towards extending the transcendental method of Kant's theoretical philosophy to the region of practical or normative thinking. ${ }^{8}$ On the other hand, Kelsen did not appreciate Cohen's approach towards legal science. For legal science was taken by Cohen to be the "scientific fact" that served as the starting point for analysing ethical principles. This was not acceptable for Kelsen's legal positivist approach, which aimed at strictly separating law and morality. Besides, Cohen's style was notoriously obscure, so that Kelsen - who was not philosophically trained - had explicit misgivings about getting things right. ${ }^{9}$

But the capacity of neo-Kantian epistemology to deal with some problems created by the basic theses of Kelsen's theory can be shown by fitting together the main tenets of the Pure Theory and those neo-Kantian elements that Kelsen appropriated.

\subsection{The main tenets of Kelsen's theory}

The core of Kelsen's theory concerning the law and legal cognition throughout all its phases from about 1920 onward is formed more or less by the following eight theses: ${ }^{10}$

(1) The Pure Theory is a theory of institutionalised legal science (understood as legal dogmatics). ${ }^{11}$

6 Cf. H. Kelsen, Hauptprobleme der Staatsrechtslehre (2 $2^{\text {nd }}$ ed., Tübingen 1923), XVII.

7 Arguably, the genesis of Kelsen's theory can be divided into four phases: a "constructivist" phase lasting until about 1916; a "neo-Kantian" phase lasting approximately until 1934, a "realist" phase lasting approximately until 1960, and a "linguo-analytic" phase lasting until Kelsen's death in 1973.

8 Cf. H. Cohen, Ethik des reinen Willens ( $2^{\text {nd }}$ ed., Berlin 1907).

9 H. Kelsen, "Rechtswissenschaft und Recht", in: ZöR 3 (1922), 103-235, at 199.

10 For further references see my Die Norm als Tatsache (Baden-Baden 1997), $217-$ 220. 
(2) The spheres of "is" and "ought" have to be strictly separated; therefore, it is not possible to deduce a normative sentence from a set of empirical sentences. ${ }^{12}$

(3) A norm is purely an element of the sphere of ought; "norm" means that something ought to be done. ${ }^{13}$

(4) The validity of a norm is identical with its existence or objectivity. ${ }^{14}$

(5) Only positive norms are the objects of legal cognition. ${ }^{15}$

(6) There is no necessary connection between the validity of norms and their content. ${ }^{16}$

(7) The norms of a legal system form an hierarchy; the validity of "lower" norms is established by "higher" norms which state the empirical conditions that have to be satisfied for the lower norms to exist (the Stufenbautheorie). ${ }^{17}$

(8) At the apex of the hierarchy of norms there is a presupposed "basic norm" establishing the validity of the highest positive norms. ${ }^{18}$

\subsection{Kelsen's employment of neo-Kantian epistemology}

Given these central theses, it is easy to see why Kelsen should be attracted to neo-Kantianism and specifically to Cohen's theory of the transcendental method in his search for a philosophical basis. His neo-Kantian epistemology - which Kelsen never laid down in a systematic way - is characterised by the following theses: ${ }^{19}$

11 Cf. H. Kelsen, Reine Rechtslehre ( $1^{\text {st }}$ ed., Leipzig/Vienna 1934), preface IX. There is an English translation by B. Litschewski Paulson and S. L. Paulson under the title Introduction to the Problems of Legal Theory (Oxford 1992).

12 Cf. H. Kelsen, Das Problem der Souveränität und die Theorie des Völkerrechts (Tübingen 1920), 33, 89.

13 Cf. H. Kelsen, Reine Rechtslehre (n.11), 20-2.

14 Cf. H. Kelsen, Reine Rechtslehre (n.11), 6-7; Rechtswissenschaft und Recht (n.19), 205-7.

15 H. Kelsen, Reine Rechtslehre (n.11), 64.

16 H. Kelsen, Reine Rechtslehre (n.11), 24.

17 H. Kelsen, Reine Rechtslehre (n.11), 62-6. If one wants to preserve the ought of the "higher" norms, which usually are empowering norms, even in their formulation, they have to be formulated somewhat like "If the legislator wants $x$ to do $y$, then $x$ ought to do $y$ ".

18 H. Kelsen, Reine Rechtslehre (n.11), 65-6.

19 The most important sources for Kelsen's neo-Kantian epistemology are Die philosophischen Grundlagen der Naturrechtslehre und des Rechtspositivismus (Berlin 1928), esp. at p.62, and the lengthy paper dealing with Fritz Sander's attacks against the Pure Theory, "Rechtswissenschaft und Recht", in: ZöR 3 (1922), 103-235. A readable shorthand version of Kelsen's neo-Kantian conception can be found in the preface to the $2^{\text {nd }}$ ed. of Hauptprobleme der Staatsrechtslehre (Tübingen 1923). There is no English translation of Rechtswissenschaft und Recht. A translation of the preface of Hauptprobleme der Staatsrechtslehre is included in the volume Normativity and Norms (ed. by S. L. Paulson and B. Litschewski Paulson (Oxford 1998), 3-22. A translation of Die 
(1) Cognition does not deal with "things-in-themselves", rather, it constitutes its own objects. ${ }^{20}$

(2) This constitution of objects is performed by applying concepts of understanding (the categories) to an "alogical" material and thus forming synthetic judgements. ${ }^{21}$

The latter thesis is specified by three further claims concerning the nature of judgements (in a logical sense):

(a) A judgement is an objective meaning-content that must be distinguished from the psychological act of judging. ${ }^{22}$

(b) The existence of a judgement is its validity or objectivity. ${ }^{23}$

(c) The judgement is identical with the cognitive object. ${ }^{24}$

Two further theses of Kelsen's neo-Kantian epistemology concern the relation between legal science and law and the role of the Pure Theory on the basis of these assumptions:

(3) Natural and legal science, understood as systems of judgements, are identical with their respective cognitive objects. Nature consists of hypothetical judgements in which the category of causality is employed. Law consists of hypothetical judgements in which the category of normative imputation is employed, following the scheme "If $x$, then coercive act $y$ ought to be executed". ${ }^{25}$

(4) The Pure Theory does not deal with the law as a "given" object; rather, it plays the part of a transcendental philosophy of law by exploring the necessary conditions of legal science. ${ }^{26}$

The last thesis, of course, is Kelsen's version of the transcendental method. The advantages of this neo-Kantian epistemology in accounting for the basic elements of the Pure Theory are obvious:

First, it offers the best possible explanation of the status of the Pure Theory. Conceiving his theory as a transcendental philosophy of legal knowledge, Kelsen accepts the "factum of legal science" as embodied in academic teaching and in legal practice, and he delimits the task of the Pure Theory to exploring the conditions that make this "factum" possible and to setting constraints for legal science to prevent its methods and results from not being

philosophischen Grundlagen can be found in the appendix of Kelsen's General Theory of Law and State (Cambridge/Mass. 1945).

20 H. Kelsen, Die philosophischen Grundlagen der Naturrechtslehre und des Rechtspositivismus (n.19), 62.

21 H. Kelsen, Rechtswissenschaft und Recht (n.19), 181-2.

22 H. Kelsen, Der soziologische und der juristische Staatsbegriff (Tübingen 1922), 81.

23 See esp. H. Kelsen, Rechtswissenschaft und Recht (n.19), 206-9.

24 H. Kelsen, Rechtswissenschaft und Recht (n.19), 182.

25 H. Kelsen, Rechtswissenschaft und Recht (n.19), 181-2.

26 H. Kelsen, Reine Rechtslehre (n.11), 36-7. 
in accordance with those presuppositions. This project is reflected in quite a number of Kelsen's writings; an example is the following crucial passage from the first edition of the Pure Theory of Law:

"The Pure Theory of Law is well aware that the specifically normative meaning of certain material facts, the meaning characterized as 'law', is the result not of a necessary interpretation, but of a possible interpretation [. . .]. However, the Pure Theory of Law does not consider it necessary to dispense therefore with the category designated by 'ought' altogether and so to dispense with a normative theory of law. [...] The possibility and the necessity of a normative theory of law is shown by the very existence of legal science over millennia [das jahrtausendalte Faktum der Rechtswissenschaft], which, in the guise of dogmatic jurisprudence, serves - so long as there is law at all - the intellectual requirements of those who concern themselves with the law. There is no reason to leave these thoroughly legitimate requirements unsatisfied and to dispense with such legal science. [. . .] So long as there is religion, there must be dogmatic theology, [. . . .] and, similarly, so long as there is law, there will be a normative legal science. [. . .] What is called for is not the abandonment of this legal science along with the category of norm, the category designated by 'ought', but the restriction of legal science to its object of cognition and the critical clarification of its methods." 27

Second, Kelsen's neo-Kantian epistemology can account for the distinction between "is" and "ought", which can be traced back to the difference between the categories of causality and normative imputation - which in turn accounts for and is derived from the difference between natural sciences and legal science.

Third, the conception explains the status of the legal norm, which is identical with the judgement of legal science. Assimilating the status of normative and natural sciences, Kelsen claims that both legal norms and laws of nature are constituted in and identical with the judgements of legal and natural sciences, respectively. Together with the fact that there are exact criteria for ascertaining the validity of legal norms, this suffices to put legal science on a level with natural science as far as the objectivity and exactness of their results are concerned. At the same time, the character of the "validity" of a norm is elucidated: It is the validity of a judgement in a logical sense.

Fourth, the neo-Kantian conception explains how Kelsen can be a cognitivist, a relativist, and a positivist, all together. $\mathrm{He}$ is a cognitivist insofar as he takes norms to be judgements in a logical sense that are objectively valid. $\mathrm{He}$ is a relativist and a positivist insofar as for him the validity of these judgements is dependent not on their corresponding to a knowledge-independent normative reality, but on their meeting the special criteria of validity laid down in the system they are part of - these point to

27 H. Kelsen, Reine Rechtslehre (n.11), 36-7 (translation from Introduction to the Problems of Legal Theory (n.19), 34-5 - translation slightly altered). 
factual acts that may vary and allow for very different and mutually incompatible normative content. Besides, legal knowledge is based, for Kelsen, on a basic norm, which can but need not be presupposed and thus in a different sense - contributes to the relative character of the law.

Fifth, the neo-Kantian conception helps to account for the hierarchical structure of the legal system. For the Stufenbautheorie requires some logic of norms; and the neo-Kantian epistemology offers a plausible basis for such a logic by taking norms to be judgements - after all, judgements are the classical elements that are subject to logical relations. Finally, the basic norm seems to be a direct result of an application of the transcendental method; Kelsen explicitly calls it a "transcendental-logical condition" for legal knowledge. ${ }^{28}$

\section{SECOND PART: SYSTEMATIC APPROACH}

\section{The transcendental method and transcendental arguments}

Although the term "transcendental method" has by no means perished with neo-Kantianism - it has been used by Karl Popper, among others - since the notorious debate between Peter Strawson and Barry Stroud has taken place, ${ }^{29}$ using the term "transcendental argument" for the procedure of justifying cognitive universals is far more popular nowadays. Therefore, in appraising Kelsen's employment of the transcendental method, a short survey of the concept of a transcendental argument might be helpful.

A classical definition of a transcendental argument is that of Stroud, who characterises transcendental arguments by maintaining that:

(1) their premises have to be justified independently of any experience about the external world,

(2) the premises cannot be rejected by the sceptic,

(3) the argument uncovers necessary conditions for thought and experience,

(4) the conclusion of the argument entails truths about the external world. ${ }^{30}$

I will rely on Stroud's definition - with the reservation that, seen in the light of neo-Kantian argumentation, Stroud's characterisation of the premises of the argument is too demanding; a neo-Kantian would think it sufficient to base the argument on the "results of the best cognitive or scientific methods available to us".

If a transcendental argument follows the Kantian or neo-Kantian tradition, it must have something to do with the "conditions for the possibility of knowledge". If knowledge is made up of true propositions about objects, then a Kantian transcendental argument aims at establishing the necessary

28 H. Kelsen, Reine Rechtslehre (n.11), 67.

29 P. F. Strawson, Individuals (New York 1959), ch.1; B. Stroud, "Transcendental Arguments", in: The Journal of Philosophy 65 (1968), 241-56.

30 B. Stroud, "Kantian Argument, Conceptual Capacities and Invulnerability", in: Kant and Contemporary Epistemology (ed. by P. Parrini, Dordrecht 1994, 231251), 231. 
conditions for (the possibility of) true propositions about objects, starting from indubitable premises.

Such transcendental arguments normally have an anti-sceptical tendency. For, as the Strawson-Stroud-debate has shown, the sceptical standpoint usually presupposes a realist point of view, whereas the significance of a transcendental argument may arguably be seen only from a non-realist point of view. So transcendental arguments might need an additional argument for the truth of non-realism (if they do not contain such an argument from the beginning).

In fact, the debate between Stroud and Strawson seems partly to be fired by the tacit assumption of both parties that realism is correct. Else it is scarcely conceivable that Stroud, by way of an attack, should point to the verification principle underlying Strawson's original argument, that Strawson should submit to the assault, and that both parties should finally agree that only a reconstruction of the argument in terms of belief might be possible. ${ }^{31}$ For an average non-realist would take the terms "exists" and "must be believed to exist" to be more or less equivalent, and he would accept the verification principle. It is possible, of course, and has been attempted by some philosophers, to produce yet another fundamental argument for non-realism Hilary Putnam's famous brains-in-a-vat-argument ${ }^{32}$ from his rather (neo)Kantian phase of internal realism offers an example. But such a proof, if valid, would still be slightly flawed; for it would just follow that knowledge or cognition were able to constitute their own foundations - the proof would be circular. Yet, a successful argument for realism would in a way be "selfrefuting": The assumption of a knowledge-independent reality would have been implicitly shown to be necessitated by the structure of our knowledge itself. Confronted with these alternatives, circularity seems to be the lesser evil. But this is no matter to be settled in a shorthand way.

The literature concerning transcendental arguments is vast. Most transcendental arguments that try to live up to Stroud's definition cannot overcome the difficulty of finding a premise that on the one hand is

31 Cf. P. F. Strawson, Skepticism and Naturalism: Some Varieties (New York 1985), 21-3. Stroud maintains that Strawson's argument - without saying so - relies on a special version of the verification principle, and that if this hidden and unfounded premise of his argument were made explicit, it would answer the sceptic directly, so that the argument would, in a way, be superfluous, unless it were reconstructed in terms of belief.

32 H. Putnam, Reason, Truth, and History (Cambridge/Mass. 1982), ch.1, 1-21. The argument resembles Descartes' construction of an evil demon: Imagine that there are some people who have been dissected by night by an evil scientist and whose brains have been put into a vat with some nourishing fluid which is at the same time responsible for absolutely everything that these people experience; and this "experience" is the same that they had before they were dissected. Can these people correctly refer to their position by thinking "We are brains in a vat"? Putnam claims that this is impossible, and I tend to think that he is right because reference to anything that we cannot come into "contact" with is impossible. In the context of Putnam's example, this is basically - and perhaps contrary to Putnam's intention - a non-realist argument: the brains in a vat cannot refer to the unknowable "fact-in-itself" that they are brains in a vat, but they refer to a world of objects that "in-itself" is made up just of artificial stimuli of the brain. 
indubitable and on the other hand is non-trivial - and to find a way of either justifying this premise or of justifying why it need not be justified. In what follows, I will just try to sketch the structure of four Kantian and neoKantian transcendental arguments of different strength. They employ three rules from modal logic, which run:

- Whatever is real, is possible: $p>\mathrm{M} p$ (")" being a kind of necessary implication).

- Whatever is possible, is necessarily possible: $\mathrm{M} p>\mathrm{N}(\mathrm{M} p)$ the characteristic axiom of S5. ${ }^{33}$

- If $q$ necessarily follows from $p$, and $p$ is necessary, then $q$ is necessary as well: $((p>q) \& \mathrm{~N} p)>\mathrm{N} q$.

Actually, it is not at all settled whether these rules - stemming from alethic modal logic - can be applied to arguments in "transcendental" logic; but, for the purposes of this paper, this will just be presupposed.

Let us first consider transcendental arguments in a Kantian vein, which aim at establishing the necessary conditions for true judgements at large. The first starting point is that of a genuine Kantian progressive transcendental argument; it relies on the thesis that the (indubitable) unity of self-awareness and propositionality are "equiprimordial". ${ }^{34}$ A fundamental version of the argument establishing the validity of cognitive universals might - very roughly, and somewhat shortened - run as follows.

\section{TA1:}

(1) Necessarily, there is the unity of self-awareness.

(2) The unity of self-awareness presupposes a capacity for forming objective judgements, i.e. of thinking true (empirical) propositions. ${ }^{35}$

(3) Therefore, it is possible to think true (empirical) propositions.

(4) Thinking true (empirical) propositions presupposes that $c$ ( $c$ standing for apriorical conditions for empirical knowledge).

(5) Therefore, necessarily, $c$.

${ }^{33} \mathrm{~S} 5$ is one of the most prominent systems of alethic modal logic; see G.E. Hughes and M.J. Cresswell, A New Introduction to Modal Logic (London 1996), 344.

34 "Equiprimordial" (gleichursprünglich) is a rather artificial term, stemming from Heidegger and having been taken up by Habermas. It is used here as a partly relational term: two elements are equiprimordial if you "can't have one without the other" and if neither is derivable from the other or from anything else. That is, the unity of self-awareness entails propositionality, and propositionality entails the unity of self-awareness, even though the concepts are not reducible to each other.

35 An objection suggesting itself is that it would not be necessary for the unity of self-awareness to exist that we are able to think "true" judgements; it would suffice that our thoughts take the form of judgements at all, be they true or false. But this objection on the one hand disregards the close connection between judgements, at least as far as they are - for philosophy in a Kantian vein constitutive of reality, and truth according to Kant; on the other hand there is strong evidence even apart from Kantian philosophy that the possibility of judging depends on most of our judgements really being true. See infra the discussion of the first premise of TA2. 
Premise (1) is the indubitable starting-point; premise (4) is the "transcendental" premise concerning the "conditions-for-the-possibility-ofcognition". There are a lot of problems with this argument, especially as regards the validity of the second premise. Nevertheless, it is rather a "minimalist" version of a synthetic or progressive transcendental argument. A more elaborate version would point out that the unity of self-awareness necessitates certain features of propositions as characterised by the Kantian categories, so that $c$ does not just denominate necessary conditions for all true empirical propositions but only for those necessarily correlated to the possibility of self-awareness.

The second starting-point is that of a less ambitious but - I think - rather attractive argument in the Kantian vein; it is the thesis that there are at least some true propositions. The argument runs as follows.

\section{TA2:}

(1) There are some knowable true propositions.

(2) The possibility of there being knowable true propositions entails $c$.

(3) Therefore, necessarily, $c$.

This sounds like a regressive argument, but it is certainly stronger than a neo-Kantian argument simply based on the fact of science. Whether it is regressive or progressive in character depends on the nature of the first premise. On the one hand, the premise is pretty unassailable because it does not presuppose any concrete knowledge, on the other hand, it is not quite immune to a radical sceptic's attack - even though Donald Davidson has attempted to give another indubitable argument for the similar thesis that we cannot be wrong in all our opinions and that, in fact, most of our opinions have to be true. ${ }^{36}$

If the first premise were just factually true, the argument would have the charm of arriving at a necessary conclusion from a factual first premise. The conclusion, however, would not amount to much - as a conjecture: it might comprise the rules of propositional logic, Tarski's Convention $T$, and something like the principle of verification. ${ }^{37}$

So much for transcendental arguments in a Kantian vein. Neo-Kantian arguments representing the transcendental method are less ambitious, relying completely on a first premise that is not necessarily valid. They might be reconstructed in two different ways, depending on what the first premise is

36 Cf. D. Davidson, "A Coherence Theory of Truth and Knowledge", in: Kant oder Hegel (ed. by D. Henrich, Stuttgart 1983, 423-38). In fact, Davidson has given another rather convincing argument for the thesis that there cannot be incomparable conceptual schemes; $c f$. D. Davidson, Inquiries into Truth and Interpretation (Oxford 1984), at ch.13. Taken together, the conclusions of these arguments and the conclusion of Putnam's brains-in-a-vat argument constitute a rather attractive basis for the possibility of objectively valid knowledge from a non-realist perspective.

37 To be sure, Kant himself would have regarded neither the rules of formal logic nor Tarski's Convention $T$ as transcendental-logical conditions, because they do not concern the special case of cognition of objects, but apply to any judgement. 
taken to be. On the one hand, Cohen's argument might be formulated using a meta-theoretical statement as its starting-point:

\section{TA3:}

(1) Those sentences that are taken to be true according to the best methods applied in our established sciences are true.

(2) The possibility of the sentences of our established sciences being true entails $c$.

(3) Therefore, necessarily, $c$.

The main problem with this argument, of course, is the first premise. Though it is just a modification of the first premise of TA2, it is neither factually nor necessarily true. It is just laid down for pragmatic reasons. An argument for the first premise might run somewhat like "Science is a fact, and what sentences could be called true if not those made out to be true by our best scientific methods?" Hence there is a conclusion according to which the presuppositions of the possibility of science necessarily are true, but this conclusion is dependent on a first premise that is neither necessarily nor factually true, but was just laid down.

On the other hand, the first premise of the argument might be formulated in a simpler way not as a meta-theoretical statement that those sentences that are made out to be true by science are true, but just as a variable for any such sentence; the argument would run:

(1) $\quad p$ [ $p$ being any sentence that is true according to established science].

(2) The possibility of $p$ entails $c$.

(3) Therefore, necessarily, $c$.

Note that to shake this argument it is not enough to show that $p$ is false; instead, it is necessary to show that $p$ cannot sensibly be called either true or false. $^{38}$

Locating Kelsen's argument in these theoretical surroundings is not difficult. His Cohen-like transcendental argument for the necessary conditions for legal science would run as follows:

\section{TA4:}

(1) Those normative legal propositions that are taken to be true according to the established methods of institutionalised legal science are true.

(2) The possibility of the normative propositions of legal science being true entails $c$.

(3) Therefore, necessarily, $c$.

Or, if the first premise is taken to be not a metatheoretical sentence about the set of true normative propositions but (any) such legal proposition itself:

38 This is so because even if $p$ is contingently false, $p$ is possible, nevertheless. The argument does not work only in case $p$ is impossible. 
(1) Op [Op being a normative sentence that is true according to the methods of institutionalised legal science].

(2) The possibility of Op being true entails $\mathrm{C}$.

(3) Therefore, necessarily, C.

Thus, Kelsen is at the same time more specific and more careless about his starting-point than Cohen. While Cohen presupposes the relatively uncontested results and methods of natural sciences and mathematics, Kelsen presupposes the methods of existing legal science and their alleged results: true normative legal propositions. On the one hand, this means that Kelsen's argument just concerns a small and special branch of knowledge. On the other hand, he more or less "brackets" the problem of whether normative legal science, whose status is prima facie a lot more doubtful than the status of the established natural sciences, is a science at all

So the most problematic part of the argument is the first premise. Though Kelsen backs it by the fact that there is an age-old legal science, he acknowledges that there is an important difference between the natural sciences based on the principle of causality and legal science, in that the existence of natural facts can be proven, whereas the existence of legal norms cannot be demonstrated. Or, to put it in a paradoxical way, though the institution of legal science is a provable fact, law is not. ${ }^{39}$ An anarchist or sceptic, Kelsen admits, need not share the legal perspective; ${ }^{40}$ he might deny seeing anything in legal procedures but brute facts.

But perhaps Kelsen is too pessimistic regarding this problem. First, on the basis of his interpretation of the transcendental method, he might have answered the sceptic arrogantly as follows: "I'm not interested in your doubts. You cannot deny there is a dogmatic legal science purporting to deal with legal norms, and all I'm telling you is what you have to pay if you want to share its perspective. You can do so or refrain from it, I don't care!' Second, even though the existence of law in a normative sense is not immune to a sceptic's attack, the thesis that it is (almost) as certain as the existence of a natural fact might possibly be defended. Kelsen himself offers an argument that can be sketched as follows: In any society, law and legal procedures are part of an existing social practice. This, at least, is a fact. But the factual procedures that might be classified as "legal" can only be determined by taking the meaning-content of certain utterances, which purport to enact law, to be valid norms, i.e. by sharing the perspective of legal science. Any other criterion either is unfit to delimit the extension of the term "law", or it presupposes this basic standard. ${ }^{41}$ Thus, even a

39 Note, by the way, the equivocation resulting from the double meaning of the expression "fact of science": on the one hand, the fact of science is the fact that there is a science, on the other hand, it is the fact as established by science. Kelsen is seldom clear about which interpretation he prefers; most often, he seems to mean both of them.

$40 C f$. H. Kelsen, Reine Rechtslehre (n.11), 36.

41 Note that this is not the same as to say "Law in a normative sense is an ideology at work in the minds of those engaged in legal procedures"; rather, it means that a conception of law as a normative system is a necessary condition for any sociological or factual conception of law. 
seemingly purely sociological concept of law presupposes the normative perspective of legal science. ${ }^{42}$ Accordingly, if the sceptic denies that there are any legal norms and that the sentence "Legally, thieves ought to be punished" is meaningful and has a truth-value, so that legal science "makes sense", he must at the same time deny that law is a social fact - which is possibly as difficult to deny as the existence of a natural fact.

This is not the place to check the soundness of the argument. For there is something deeper behind Kelsen's reservations about the status of legal cognition. Though he usually claims that the legal ought is a purely formal category that simply serves to delimit the object of legal science and to establish its autonomy, ${ }^{43}$ at times he suggests that there can be only one material ought that unconditionally determines the ways in which we should act, so that something that ought to be done according to a legal norm ought to be done "absolutely" as well. This is shown, e.g, in formulations of the basic norm that do not restrict it to the law, like "Coercion should be exerted according to the conditions laid down by the fathers of the historically first constitution and by the authorities delegated by them" 4 (instead of "Legally, coercion should be exerted etc."). Of course, it is easy to be a sceptic concerning the truth of such a sentence, which amounts to the claim that the law should be obeyed.

A trivial solution to this problem of separating the idea of a legal ought from the idea of an absolute ought consists, as suggested just now, in adding the adverb "legally" to the formulation of each legal norm to indicate that it is valid just inside the legal language-game. A more sophisticated solution can be found in a quasi "subterranean" tendency of Kelsen's writings throughout all phases of the Pure Theory: the tendency to regard the law simply as a huge semantic complex determining the meaning of the expression "legal act". ${ }^{45}$ According to this conception, the legal rule is no "action" norm saying, "If $x$, then coercive act $y$ ought to be executed" but just a kind of Searlian constitutive rule saying, "If $x$, then coercive act $y$ counts as a legal $a c t$ "; and all legal phenomena could be reduced to rules of this kind. Relying on this conception would not only remove doubts about the "validity" of the legal perspective, it would also deactivate the conflict between law and morality. Besides, it would give a basis to Kelsen's numerous explanations of the legal norm as a "scheme of interpretation" for reality. ${ }^{46}$ The price to be paid, though, would be rather high: The action-orientated normativity contained in legal language has to be neglected, and Kelsen's claim that the Pure Theory tries to capture the meaning of "all those thousands of

42 In fact, the whole first part of Der soziologische und der juristische Staatsbegriff (n.22) is devoted to expounding this argument.

43 Cf. H. Kelsen, Reine Rechtslehre (n.11), 21.

44 H. Kelsen, Reine Rechtslehre (n.11), 21.

45 This conception is prominent even in the first ed. of Hauptprobleme der Staatsrechtslehre (Tübingen 1911), 254-5, where Kelsen defines the legal rule as a hypothetical judgement serving to impute acts to the State - and thus interpreting them as legal acts. For a later version see H. Kelsen, Reine Rechtslehre (n.11), 45.

46 Cf. H. Kelsen, Reine Rechtslehre (n.11), 4-5. 
[normative] utterances that make up our everyday legal life" 47 would be somewhat spurious.

Anyway, what would be the consequence if we take Kelsen's concessions regarding the "avoidability" of the perspective of legal dogmatics seriously or just stick to the "arrogant" answer to the sceptic given above? The transcendental argument would still be valid as such, for the validity of an argument is not impaired if the premises cannot be established as true. But, as the possibility of $\mathrm{O} p$ is contestable, the conclusion that $c$ necessarily obtains cannot be inferred, even if the transcendental premise $(\mathrm{M}(\mathrm{O} p)>c)$ can be shown to be true. It is questionable whether an argument of this purely hypothetical kind might still be called "transcendental". It certainly does not live up to the criteria named by Stroud. Still, the argument concerns necessary conditions for a special branch of knowledge, even if this knowledge should be disputable or hypothetical; and Kelsen is right in maintaining that there is an age-old institutionalised normative legal science following certain methods and asserting its results with a claim to truth. In my eyes, this should be enough to term Kelsen's argument a "transcendentalargument-in-a-neo-Kantian-sense". ${ }^{48}$

\section{Necessary presuppositions of legal science as conceived by the Pure Theory}

So far it was shown that Kelsen, in his neo-Kantian phase, takes his own legal theory to be employing the transcendental method developed by Hermann Cohen. He proffers a hypothetical transcendental argument that starts with the problematic fact of institutionalised legal science and then points out what the legal normative propositions, uttered by legal dogmatists with a claim to truth, universally presuppose. The question remains: What are the universal presuppositions of institutionalised legal science, according to Kelsen? - Roughly, Kelsen names ten "basics" of legal cognition (which,

47 H. Kelsen, Reine Rechtslehre (n.11), 65-6.

48 Stanley L. Paulson has repeatedly and correctly pointed out that Kelsen, in his neo-Kantian conception, tries to construct a transcendental argument of the "regressive" type (see esp. his paper "On Transcendental Arguments, their Recasting in Terms of Belief, and the Ensuing Transformation of Kelsen's Pure Theory of Law", in: Notre Dame Law Review 75 (2000), 1775-95); see further "The neo-Kantian Dimension of Kelsen's Pure Theory of Law", in: Oxford Journal of Legal Studies 12 (1992), 318-25). Paulson claims that Kelsen's project has failed, but the reasons he gives are not cogent. Paulson reconstructs Kelsen's transcendental argument as follows: "1. One has cognition of legal norms. 2. Cognition of legal norms is possible only if the category of 'ought' or 'Sollen' is presupposed. 3. Therefore, the category of 'ought' or 'Sollen' is presupposed" $(1790-1)$. He then maintains that the second premise is not tenable because there always are alternative ways of accounting for the "legal data". But this is not convincing, because Kelsen's starting-point are not any "data" (whatever this might be) given to legal cognition, but the propositions of institutionalised legal dogmatics, which he takes to be normative from the beginning. Therefore, the way to attack Kelsen's argument would not be to say that he has got the second premise wrong, because there are other ways of approaching law as a social practice than that of legal dogmatics, but to say that he gives a mistaken phenomenology of legal dogmatics. This is - mainly - a matter of the first premise. 
inevitably, overlap with the basic theses of the Pure Theory and its neoKantian epistemology of norms listed above):

\subsection{General presuppositions of legal and natural science}

On the one hand, there are conditions that Kelsen thinks to be necessary for any piece of knowledge co-ordinated to either natural or legal science:

(1) It takes the form of a hypothetical judgement. ${ }^{49}$

(2) It is consistent with all other judgements deemed valid. ${ }^{50}$

(3) It is verifiable by exact (empirical) criteria. ${ }^{51}$

It is difficult to say whether these conditions might be called "transcendental". The demand of consistency, on the one hand, applies to any true judgement and is part of formal logic, so it is no special feature of science's constituting its object. The demand that scientific knowledge has to take the form of an hypothetical judgement, on the other hand, and the demand that there has to be an exact way of verifying a scientific judgement are characteristic for natural and legal sciences, so they might be called "transcendental" conditions of these sciences (if we disregard that the first condition does not concern the meaning but the structure of scientific knowledge). The problem with these conditions is, however, that they stem from a rather peculiar neo-Kantian-cum-positivist conception of science. They are expressive of Kelsen's tendency to assimilate the method of legal science to the method of natural science, and it is doubtful whether the large majority of legal dogmatists even at Kelsen's times would subscribe to them - at least when this conception of science is coupled with normativism. Condition (3), by the way, is mainly responsible for Kelsen's thesis that law and morality must be separated.

\subsection{Presuppositions of legal science}

On the other hand, there are conditions that Kelsen takes to be necessary just for legal science and that serve to distinguish legal science from natural sciences. Arguably, they are the following:

(4) The hypothetical judgement of legal science is structured as a legal rule, i.e. it connects a legal consequence, which is an act of coercion, to a legal condition. ${ }^{52}$

(5) The meaning of the "connector" between legal condition and legal consequence is that of normative imputation. ${ }^{53}$

(6) Any legal norm, with the exception of norms at the highest level, fulfils the criteria of validity laid down in a norm at a meta-level. ${ }^{54}$

(7) Any norm at the "highest" level is valid..$^{55}$

49 Cf. H. Kelsen, Hauptprobleme der Staatsrechtslehre ( $2^{\text {nd }}$ ed., n.19), preface VI.

50 Cf. H. Kelsen, Reine Rechtslehre (n.11), 136.

51 Cf. H. Kelsen, Reine Rechtslehre (n.11), preface IX, 64.

52 Cf. H. Kelsen, Reine Rechtslehre (n.11), 22-4.

53 Cf. H. Kelsen, Reine Rechtslehre (n.11), 22.

54 Cf. H. Kelsen, Reine Rechtslehre (n.11), 63-4.

55 Cf. H. Kelsen, Reine Rechtslehre (n.11), 66-7. 


\section{Northern Ireland Legal Quarterly [Vol. 55, No. 4]}

(8) Any legal norm is part of an autonomous legal system consisting only of hypothetical judgements of the same kind. ${ }^{56}$

(9) The legal system is unique, i.e. there are no two different valid legal systems at the same time. ${ }^{57}$

(10) Finally, the legal system is all in all efficacious, i.e. in a certain degree people act according to the norms contained in it. ${ }^{58}$

To be sure, this list is rather roughly hewn - some of the conditions certainly cannot be called "transcendental" in Kant's sense, some are contestable, some of the presuppositions merge into each other, and some are even prone to result in contradictions. It's just a tentative sketch. Kelsen himself never drafted a list like this and did not even attempt to systematise the necessary conditions for legal science.

But how does one get at these universal presuppositions of any legal proposition? Pointing to the transcendental argument given above is not enough; it is not self-evident that the possibility of the truth, e.g., of the sentence "Legally, if somebody steals, he ought to be punished" necessarily implies all ten conditions named above. And Kelsen does not simply employ the argument that any utterance that both asserts a legal proposition and denies its presuppositions is self-refuting or inconsistent, like, e.g. "Legally, if somebody steals, he ought to be punished; but this does not fulfil any criteria for legal validity." Instead, Kelsen's strategy, which is only implied in his writings, is rather complex. The first step is to give a phenomenology of existing legal dogmatics. The second step consists in "rationally reconstructing" the results by mutually accommodating the superficial structure-and-meaning of factual legal utterances and their necessary implications in accordance with the general demands of science. Both procedures are principally prone to errors and, thus, assailable.

The general presuppositions of science - conditions (1) to (3) - are laid down by Kelsen in a rather apodictic way. The special demands of legal science partly combine those general demands with the implications of actual procedures in legal dogmatics: The uniqueness of the legal system is implied by the demand of consistency; the necessary existence of "meta-level-norms" derives from the demand that there should be exact criteria of truth or validity. Typical elements of legal science alone are the demand that the legal norm should connect an act of coercion to a certain condition by means of the category of normative imputation, and the demand that the legal order should be efficacious. But Kelsen does not take these postulates simply to be implied by the factual procedures of legal science, instead, he gives additional arguments: Without the category of normative imputation an autonomous legal science would not be possible; ${ }^{59}$ the element of coercion serves to distinguish moral and legal norms even by their content; and the

56 H. Kelsen, Der soziologische und der juristische Staatsbegriff (n.22), 37.

57 H. Kelsen, "Naturrecht und positives Recht", in: Die Wiener Rechtstheoretische Schule (ed. by H. Klecatsky et al., Vienna 1968, 215-244), 222.

58 Cf. Hans Kelsen, Reine Rechtslehre (n.11), 69-72.

$59 C f$. H. Kelsen, Das Problem der Souveränität (n.12), 10 n. 
demand of efficacy follows partly from Ernst Mach's principle of economy of thought (Denkökonomie), ${ }^{60}$ which, therefore, might be added to the list of presuppositions of science in general.

\subsection{The category of ought and the basic norm}

The named reservations apart, the list given above covers about all presuppositions of legal science. This might be surprising, for reading Kelsen's texts - especially his major ones - leaves one with the impression that there are just two candidates for transcendental-logical conditions for law, both of which are missing in the list, namely, the category of ought, and the basic norm.

But actually, they are not missing. As was shown above, in his neo-Kantian legal epistemology, Kelsen identifies the legal ought with the category of normative imputation. So conditions (4) and (5) concern the ought of the legal norm which is a category of relation having a status comparable to that of Kant's category of causality but meaning something different. Its meaning is that of the relation between antecedens and consequens in the judgement "If somebody steals, he ought to be punished". This relational conception of the ought involves a number of problems. One of the more important ones was mentioned above: It is scarcely compatible with Kelsen's Stufenbautheorie, i.e. with his theory that there necessarily are several layers of law, at least one of which consists of empowering norms. For it is difficult to see normative imputation as the ought that is operative in empowering norms (or in the individual norms of judges' decisions). Maybe Kelsen would have fared better if he had taken the ought to be a category of modality, even if this had destroyed the parallelism between normativity and causality.

Finally, there is the basic norm to account for. The basic norm, according to Kelsen, is a norm that - as a transcendental-logical condition - is necessarily presupposed by anybody who considers the highest level of positive norms in a legal system to be valid. Kelsen explains the basic norm as if it were the paradigmatic result of applying the transcendental method:

"In formulating the basic norm, the Pure Theory of Law is not aiming to inaugurate a new method for jurisprudence. The Pure Theory aims simply to raise to the level of consciousness what all jurists are doing (for the most part unwittingly) when, in conceptualizing their object of enquiry, they reject natural law as the basis of the validity of positive law, but nevertheless understand the positive law as a valid system, that is, as norm. With the doctrine of the basic norm, the Pure Theory analyses the actual process of the long-standing method of cognizing positive law, in an attempt simply to reveal the transcendental logical conditions of that method." $" 61$

But this and any other explanation that Kelsen gives of the basic norm's transcendental-logical character applies almost to any presupposition of law.

60 H. Kelsen, Das Problem der Souveränität (n.12), 98-9.

61 H. Kelsen, Reine Rechtslehre (n.11), 67 (translation from Introduction to the Problems of Legal Theory (n.19), 58). 
And the status of the basic norm remains vague. To be sure, there is one substantial definition according to which the basic norm is a non-positive presupposed norm validating the highest positive legal norm - the constitution - by ordering that one should act in accordance with it ${ }^{62}$ so that the basic norm in a way grounds condition (7). However, as H. L. A. Hart among others has pointed out, the necessity of this function of the basic norm is doubtful. If asked why she applies or takes to be valid the norms of the constitution, it is not likely that the average jurist will answer "Oh, well, now you ask me - I presuppose another norm according to which the constitution is valid"; rather, she will probably answer "Oh, well, after all it is the highest norm of our legal system in force, so I just presuppose it to be valid. Everybody does so, and as you can see, it works!"

But there is also a "mysterious" side of the basic norm that is mainly responsible for the thousands of pages concerning this concept in secondary literature: According to its "mysterious" side, the basic norm is an omnipotent abstract epistemic concept, the origin (Ursprung) of the legal system, ${ }^{63}$ a hypothesis in the sense of Cohen and Plato, ${ }^{64}$ the vanishing-point of the legal system in which all its transcendental conditions merge. ${ }^{65}$ Or to put it in a more vulgar way: it is a kind of "transcendental trashcan", simply a token for the universal presuppositions of legal science.

On this view, the answer to the question of where there is a place for the basic norm in the list of legal presuppositions named above is not difficult: the expression "basic norm" is just a unifying sign for - at least - the presuppositions bearing the numbers (6) to (10) and perhaps even for all of them.

\subsection{The triviality of the Pure Theory}

After all this, the question might arise of whether the results that Kelsen's theory presents are not rather trivial. Instead of revealing "transcendental secrets" to us, as we might have expected, Kelsen, though at times raising the claim to provide a transcendental logic, simply performs a contestable metatheoretical presuppositional analysis of existing legal dogmatics. ${ }^{66}$

62 H. Kelsen, Reine Rechtslehre (n.11), 65.

63 H. Kelsen, Rechtswissenschaft und Recht (n.11), 233.

64 H. Kelsen, "The Pure Theory of Law, 'Labandism', and Neo-Kantianism. A Letter to Renato Treves", in: Normativity and Norms (ed. by S. L. Paulson and B. Litschewski Paulson, Oxford 1998, 169-176), 174.

65 See especially H. Kelsen, Die philosophischen Grundlagen der Naturrechtslehre und des Rechtspositivismus (n.19), 295-300.

66 On this problem see the excellent paper by Stefan Hammer, "A Neo-Kantian Theory of Knowledge in Kelsen?", in: Normativity and Norms (ed. by S. L. Paulson and B. Litschewski Paulson, Oxford 1998, 177-194, 186-7: "It might well be argued that Kelsen's position is plausible simply as that of a neo-Kantian who takes as his point of departure 'the fact of legal science', where the required presuppositions are unquestioned and the task of bringing these presuppositions to light is all that remains. Such an interpretation, however, would reduce Kelsen's effort, together with that of his neo-Kantian predecessors, to a mere analysis of scientific method, with the result that their common claim to establishing the epistemological validity of scientific knowledge, as it is given in the various sciences, is in effect dismissed." This analysis is quite correct; the only problem 
But, first, even if Kelsen might have been more cautious in his terminology, he shouldn't be blamed for his scientific retentiveness alone: "all there is to give he offers", once we accept his notion of science. Second, the status of presuppositional analysis in general gains importance on the background of Kelsen's neo-Kantian non-realist epistemology, according to which the presuppositions of legal science are one with the necessary elements of law. Presuppositional analysis takes the place of an "ontology of law", so to speak. Third, one must keep in mind that Kelsen's main concern is a critical one. In this sense he is a true Kantian. He wants to restrict tendencies in legal science that are not in accordance with its own presuppositions and with the demands that any science worth the name has to fulfil. Accordingly, Kelsen's theory of legal concepts is characterised by its "reductionism": for Kelsen, any legal concept is acceptable for science only if its extension can be determined exclusively by relying on the legitimate normative judgements of legal science. Consequently, the central legal concepts of "state", "person", "duty", "right", etc., do not denote any autonomous entities; instead, they may completely be explained in terms of the legal rules that in turn embody the necessary presuppositions of legal science. ${ }^{67}$ Thus, the thesis that the law is entirely made up of the normative judgements of legal science, which are verifiable by objective criteria, has a critical tendency that is possibly the most substantial achievement of Kelsen's neo-Kantian phase.

\section{CONCLUSION}

At the end of this paper, it might seem as if the topic of this colloquium, which is "Law and Objectivity in the Work of Hans Kelsen", has been dealt with just in passing or indirectly. But this impression is misleading. For after what has been said, in his neo-Kantian phase, Kelsen's likely, only at first glance surprising, rather short and snappy answer to the question "Why is the law objective?" is - perhaps - obvious.

It would be: "Because there is a legal science".

I hope it has been made clear what he would have meant by this.

with it is that, on the one hand, its result does not speak - as Hammer would have it - against, but rather in favour of Kelsen pursuing a neo-Kantian project, and that, on the other hand, it is illusory anyway to try to "establish the epistemological validity of scientific knowledge", unless by working out those elements necessary for scientific statements to have a meaning and a truth-value. So the rather disparaging tone is not appropriate. And Hammer has not convincingly argued for the case that Kelsen's theory does not even achieve this modest aim.

${ }^{67} C f$. H. Kelsen, Reine Rechtslehre (n.11), 53-9. 